\title{
Penerapan Model Pembelajaran Interaktif untuk Meningkatkan Aktivitas dan Hasil Belajar Matematika Kelas V Sekolah Dasar
}

\author{
Puri Astuti \\ SD Negeri Sarireja 01 \\ puriastuti6@gmail.com
}

\section{Article History}

received 3/12/2020

revised $17 / 12 / 2020$

accepted $31 / 12 / 2020$

\begin{abstract}
The formulation of the research problem is how the learning process, increasing student activity and learning mathematics outcomes through interactive learning models. The research subjects were fifth grade students of SD Negeri Sarireja 01. This research was a classroom action research conducted in 2 cycles. In the first cycle, the average student activity score obtained was 12.9 in the medium category. In cycle II, the average score of student activity was 17.3 in the high category. The increase in student learning outcomes can be seen from the average formative test scores that the researchers gave at the end of each cycle and the percentage of complete learning. In the first cycle, the percentage of students who finished studying was $57.9 \%$. In the second cycle the percentage of students who completed $73.7 \%$. Mastery learning reached $73.7 \%$, exceeding the success indicator, namely learning mastery up to $68 \%$. The conclusion in this study is that the interactive learning model can improve the quality of learning, student activities and learning outcomes of mathematics in the matter of calculating the volume of blocks and triangular prisms.
\end{abstract}

Keywords: student activities, learning outcomes, interactive learning models

\begin{abstract}
Abstrak
Rumusan masalah penelitian ini adalah bagaimana proses pembelajaran, peningkatan aktivitas peserta didik dan hasil belajar Matematika melalui model pembelajaran Interaktif. Subjek penelitian adalah Peserta Didik kelas V SD Negeri Sarireja 01. Penelitian ini merupakan penelitian tindakan kelas yang dilaksanakan dalam 2 siklus. Pada siklus I rata-rata skor aktivitas peserta didik yang diperoleh adalah 12,9 dengan kategori sedang. Pada siklus II rata-rata skor aktivitas peserta didik adalah 17,3 dengan kategori tinggi. Meningkatnya hasil belajar peserta didik terlihat dari rata-rata nilai tes formatif yang peneliti berikan pada akhir setiap siklus dan persentase ketuntasan belajarnya. Pada siklus I persentase peserta didik yang tuntas belajar $57,9 \%$. Pada siklus II persentase peserta didik yang tuntas $73,7 \%$. Ketuntasan belajar mencapai $73,7 \%$ melebihi indikator keberhasilan yaitu ketuntasan belajar sampai $68 \%$. Kesimpulan dalam penelitian ini adalah model pembelajaran interaktif dapat meningkatkan kualitas pembelajaran, aktivitas peserta didik dan hasil belajar matematika pada materi menghitung volume balok dan prisma segitiga.
\end{abstract}

Kata kunci: aktifitas peserta didik, hasil belajar, model pembelajaran interaktif

Social, Humanities, and Education Studies (SHEs): Conference Series https://jurnal.uns.ac.id/shes

p-ISSN 2620-9284

e-ISSN 2620-9292 


\section{PENDAHULUAN}

Pendidikan merupakan proses yang sangat krusial dalam membangun sebuah negara agar menjadi maju dan menuju kearah yang lebih baik. Melalui pendidikan akan dihasilkan manusia-manusia ungguldan potensial bagi kepentingan dirinya maupun negara secara keseluruhan. Pendidikan juga dapat dikatakan sebagai investasi menuju perubahan yang terencana, bertahap dan berkesinambungan. Keberhasilan pendidikan pada hakekatnya merupakan keberhasilan dalam proses pembelajaran, sehingga untuk meraih hasil yang optimal dalam pendidikan, maka pembelajaran perlu dibenahi dan ditingkatkan kualitasnya.

Pembelajaran matematika yang diamanatkan kurikululum pada intinya adalah agar peserta didik mampu menggunakan matematika yang dipelajarinya dalam kehidupan sehari-hari dan untuk mata pelajaran lain yang memanfaatkannya. Matematika mempunyai peran besar dalam kehidupan sehari-hari. Hampir tiap hari kehidupan kita melibatkan kegiatan yang bersifat matematika.

Dipandang dari hakekat ilmu, matematika merupakan ilmu yang bersifat deduktif aksiomatik, artinya matematika terorganisasikan dari unsure-unsur yang tidak didefinisikan, berupa aksioma-aksioma. Hilbert (dalam The Liang Gie, 1981:37) berpandangan bahwa sifat alami matematika adalah sebagai system lambing yang formal. Matematika bersangkut paut dengan sifat structural dari symbol-simbol dan proses pengolahan terhadap simbol-simbol itu.

Materi yang diajarkan di Pendidikan Dasar dan Menengah disebut matematika sekolah. Matematika sekolah mempunyai ciri-ciri: 1) memiliki objek abstrak; 2) memiliki pola deduktif dan konsisten; 3) terkait dengan perkembangan IPTEK (Depdikbud, 1993:198). Matematika sekolah mengandung pengertian bahwa materi dan pola pikirnya disesuaikan dengan proses kemampuan peserta didik. Meskipun matematika sekolah mempunyai objek yang abstrak, namun pengajarannya dapat dimulai dari objek kongkrit.

Menurut Jackson (dalam Lapono, 2009:3-105) mengatakan bahwa secara umum matematika adalah "penting bagi kehidupan masyarakat." Oleh karena itu, matematika dimasukkan dalam kurikulum sekolah. Matematika diajarkan di sekolah dalam rangka memenuhi kebutuhan jangka panjang bagi peserta didikdan masyarakat. Hal ini berarti bahwa seseorang harus mempunyai kesempatan yang banyak untuk belajar matematika, kapan dan di mana saja sesuai dengan kebutuhan akan matematikanya sendiri. Kaum absolutis berpendapat bahwa algoritma matematika telah disusun sedemikian rupa dan dilengkapi dengan alat hitung yang canggih (seperti kalkulator dan komputer). Oleh karena itu, anak maupun masyarakat tidak perlu belajar banyak tentang matematika.

Hasil belajar menggambarkan kemampuan peserta didik dalam mempelajari sesuatu. Hal ini sesuai dengan pendapat Sudjana (2002:50) yang menyebutkan bahwa: "Hasil belajar adalah kemampuan yang dimiliki atau dikuasai peserta didiksetelah menempuh proses belajar". Hasil belajar mencakup kemampuan kognitif (intelektual), afektif (sikap), dan kemampuan psikomotorik (bertindak). Harus diakui bahwa dalam proses belajar mengajar, terutama yang berkenaan dengan perubahan konsep sistem persamaan linier dua variabel, sedikit sekali kemampuan yang berkenaan dengan sikap, yang lebih banyak adalah aspek kognitif dan psikomotorik. Dalam aspek kognitif ada enam unsur yang saling berkaitan satu dengan yang lainnya, yaitu pengetahuan, pemahaman, aplikasi, analisis, sintesis, dan evaluasi.

Dalam pengertiannya hasil belajar di sini disamakan dengan prestasi belajar. Prestasi belajar sebagai kemampuan seseorang untuk mencapai pengetahuan yang diperoleh melalui pengalaman belajarnya (Suryabrata, 1983:35). Hamalik (2005:18) menyebutkan bahwa prestasi belajar adalah kemampuan aktual yang diukur secara langsung. Dari definisi di atas dapat disimpulkan bahwa pada dasarnya prestasi belajar 
menggambarkan tingkat penguasaan peserta didiktentang materi pelajaran yang telah dipelajari di sekolah yang biasanya dinyatakan dengan nilai-nilai individual.

Pembelajaran pada hakikatnya merupakan suatu proses interaksi antara guru dengan peserta didik, baik interaksi secara langsung seperti kegiatan tatap muka maupun secara tidak langsung, yaitu dengan menggunakan berbagai media pembelajaran ( Rusman, 2010:134).

Dalam pembelajaran terdapat dua kegiatan pokok yaitu peserta didik belajar dan guru mengajar. Hakekat mengajar menurut Pasaribu dan Simanjuntak (1982:123) mengajar adalah menanamkan pengetahuan pada anak. Kalau pengertian dianut maka tujuannya adalah penguasaan pengetahuan oleh anak. Hal ini berarti anak pasif guru centered. Guru Berperanan, lagi bahan pelajaran bersifat intelektualitas.

Mengajar adalah menyampaikan pengetahuan kepada anak. Kalau ini yang dianut maka masalahnya hampir sama seperti hal tersebut. Hanya disini ditekankan penyampaian pewarisan pengetahuan (kebudayaan) pada hal diharapkan dari anak mengembangkan kebudayaan dengan menciptakan kebudayaan yang selaras dengan tuntutan zaman.

Mengajar adalah suatu kegiatan mengorganisasi (mengatur) lingkungan sebaikbaiknya dan menghubungkannya dengan anak sehingga terjadi proses belajar. Kalau pengertian ini yang dianut maka penegertiannya Sama dengan pengertian mendidik. Guru Hanya membimbing (mengatur lingkungan) anak yang belajar untuk menyesuaikan dirinya dengan lingkungan.

Jadi mengajar dapat diartikan menanamkan pengetahuan, menyamapaikan pengetahuan dan kegiatan mengorganisasi (mengatur) lingkungan untuk menyampaikan sebuah ilmu atau ketrampilan.

Model pembelajaran adalah suatu rencana atau pola yang dapat digunakan untuk membentuk kurikulum (rencana pembelajaran jangka panjang), merancang bahan-bahan pembelajaran, dan membimbing pembelajaran di kelas atau yang lain (Joyce \& Weill dalam Rusman, 2010:133). Model pembelajaran dapat dijadikan pola pilihan, artinya para guru boleh memilih model pembelajaran yang sesuai dan efisien untuk mencapai tujuan pendidikannya.

Suatu model pembelajaran harus mempunyai perangkat yang dinamakan (1) urutan langkah pembelajaran; (2) prinsip reaksi; (3) sistem sosial; dan (4) sistem pendukung. Urutan langkah pembelajaran adalah fase-fas atau tahap-tahap yang harus dilakukan guru bila menggunakan model pembelajaran tertentu. Prinsip reaksi adalah pola perilaku guru daam memberikan reaksi terhadap perilaku peserta didik saat belajar. Sistem sosial adalah pola hubungan guru dengan peserta didik pada saat mempelajari bahan pelajaran.

Model pembelajaran interaktif sering dikenal dengan nama pendekatan pertanyaan anak. Model ini dirancang agar peserta didik akan bertanya dan kemudian menemukan jawaban pertanyaan mereka sendiri (Fair \& Cosgrove dalam Rusman, 2010). Meskipun anak-anak mengajukan pertanyaan daam berbagai kegiatan bebas, pertanyaan-pertanyaan terebut akan terlalu lebar dan seringkali kabur sehingga kurang terfokus. Guru perlu mengambil langkah khusus untuk mengumpulkan, memilih dan mengubah pertanyaan-pertanyaan tersebut dalam kegiatan khusus. Pembelajaran interaktif merinci langkah-langkaini dan menampilkan suatu strutur untuk suatu pelajaran matematika yang melibatkan pengumpulan dan pertimbangan terhadap pertanyaan-pertanyaan perserta didik sebagai pusatnya (Rusman, $2010: 48$ )

\section{METODE}

Penelitian ini adalah penelitian tindakan kelas dengan menerapkan model pembelajaran interaktif. Penelitian ini dilaksanakan pada peserta didik kelas V SD Negeri Sarireja 01 Kecamatan Tanjung yang berjumlah 38 peserta didik, pada semester II Tahun Pelajaran 2019/2020. Penelitian ini merupakan penelitian tindakan 
kelas yang dilaksanakan dalam 2 siklus. Setiap siklus meliputi perencanaan, pelaksanaan tindakan, observasi, evaluasi, dan refleksi. Untuk memperoleh data hasil belajar dalam penelitian ini menggunakan kuis yang diberikan pada peserta didik setiap akhir siklus. Berdasarkan hasil penelitian, meningkatnya aktivitas peserta didik dapat dilihat dari hasil pengamatan yang dilakukan disetiap siklus. Pada siklus I ratarata skor aktivitas peserta didik yang diperoleh adalah 12,9 dengan kategori sedang. Pada siklus II rata-rata skor aktivitas peserta didik adalah 17,3 dengan kategori tinggi. Meningkatnya hasil belajar peserta didik terlihat dari rata-rata nilai tes formatif yang peneliti berikan pada akhir setiap siklus dan persentase ketuntasan belajarnya. Pada siklus I nilai rata-rata yang diperoleh adalah 61,8 dan persentase peserta didik yang tuntas belajar $57,9 \%$ dan peserta didik belum tuntas $42,1 \%$. Pada siklus II nilai ratarata yang diperoleh adalah 70,5 dan persentase peserta didik yang tuntas $73,7 \%$ dan peserta didik belum tuntas $26,3 \%$. Ketuntasan belajar mencapai $73,7 \%$ melebihi indikator keberhasilan yaitu ketuntasan belajar sampai $68 \%$.

\section{HASIL DAN PEMBAHASAN}

Hasil belajar matematika peserta didik kelas V SD Negeri Sarireja 01 semester II tahun pelajaran 2019/2020 pada kondisi awal rendah. Hasil belajar matematika rendah dapat dilihat pada hasil tes pada kompetensi dasar 3.1 mengenal konsep perpangkatan dan penarikan akar bilangan pangkat dua dan bilangan pangkat tiga sederhana dan 4.7 menggunakan kubus satuan untuk menghitung volume berbagai bangun ruang sederhana, dari 38 peserta didik yang memperoleh nilai 20 ada 2 peserta didik, yang memperoleh nilai 30 ada 2 peserta didik, yang memperoleh nilai 40 ada 3 peserta didik, yang memperoleh nilai 50 ada 5 peserta didik, yang memperoleh nilai 60 ada 8 peserta didik, yang memperoleh nilai 70 ada 12 peserta didik, dan yang memperoleh nilai 80 ada 6 peserta didik. Rata-rata kelasnya adalah 47,4\% Rata-rata tersebut masih dibawah KKM yaitu 67.

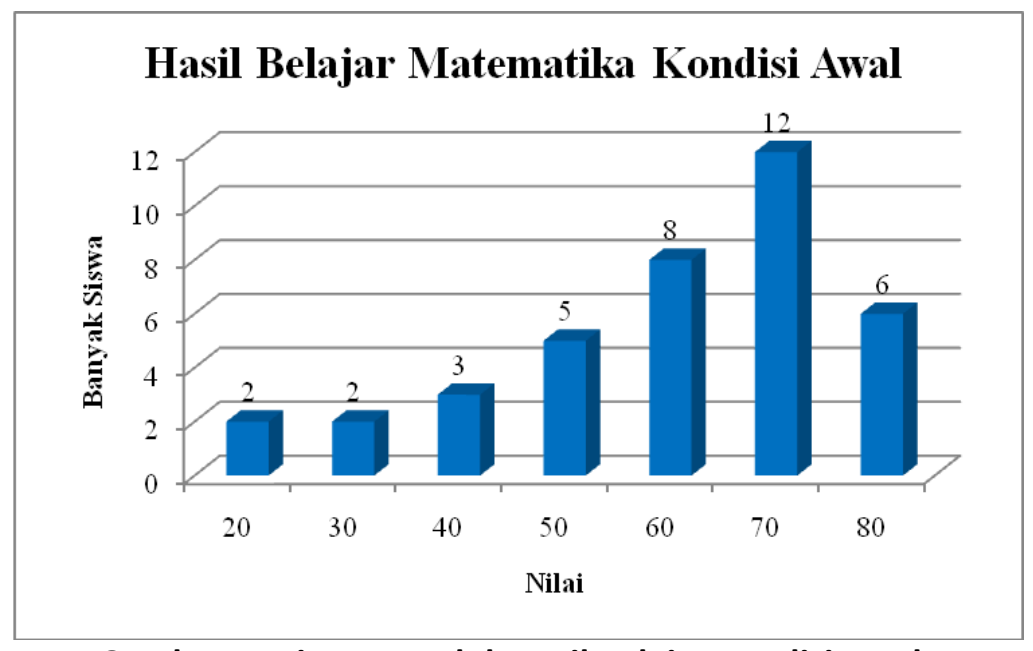

Gambar 1. Diagram Balok Hasil Belajar Kondisi Awal

Dalam pelaksanaan pada siklus 1 meliputi tahap perencanaan tindakan, pelaksanaan tindakan dan observasi serta refleksi. Pada kegiatan perencanaan yang dilakukan adalah sebagai berikut: (a) Untuk melakukan penelitian tindakan kelas yang berkenaan dengan kemampuan peserta didik dalam mendeskripsikan "Menentukan volume balok dan volume prisma segitiga" Peneliti meminta bantuan dari teman sejawat dan berkonsultasi di dalam mengungkap dan memperjelas masalah yang peneliti hadapi untuk mencari jalan pemecahan tersebut; (b) Membuat rencana perbaikan pembelajaran yang berisikan skenario pembelajaran / langkah-langkah 
pembelajaran, penekanannya pada penggunaan media pembelajaran dalam bentuk gambar, dan gambar bangun serta pendekatan model pembelajaran interaktif; (c) Menyusun alat observasi sebagai panduan bagi pengamat dalam mengamati pelaksanaan proses pembelajaran; (d) Merancang alat evaluasi yang berupa tes formatif, lembar kerja peserta didik, dan pekerjaan rumah; (e) Rencana pembentukan kelompok. Pada tahap pelaksanaan tindakan, peneliti melaksanakan tindakan sesuai dengan RPP yang telah dibuat sebelumnya. Pengamatan dilaksanakan selama proses pembelajaran berlangsung oleh teman sejawat. Hal yang diamati yaitu aktivitas guru selama mengajar dan aktivitas peserta didik selama jalannya proses pembelajaran dengan menggunakan media pembelajaran dan menggunakan pendekatan model pembelajaran interaktif, kemudian pengamat mencatat semua temuan pada saat proses pembelajaran berlangsung termasuk hasil yang dicapai peserta didik.

Tabel 1. Hasil Pengamatan Aktivitas Peserta Didik pada siklus I

\begin{tabular}{|c|c|c|c|}
\hline No & Aktivitas yang diamati & Jumlah & Rata-rata \\
\hline 1 & Memperhatikan penjelasan guru & 104 & 2.7 \\
\hline 2 & Ikut aktif dalam berdiskusi kelompok & 92 & 2.4 \\
\hline 3 & Menanyakan yang kurang dimengerti & 65 & 1.7 \\
\hline 4 & Merespon pertanyaan & 67 & 1.8 \\
\hline 5 & $\begin{array}{l}\text { Mengkomunikasikan gagasan dalam } \\
\text { kelompoknya }\end{array}$ & 60 & 1.6 \\
\hline 6 & $\begin{array}{l}\text { Perilaku yang menyimpang dalam KBM } \\
\text { (tidur, makan, bermain, berbicara yang } \\
\text { bukan pelajaran, dan sebagainya }\end{array}$ & 103 & 2.7 \\
\hline & Jumlah & 491 & 12.9 \\
\hline & Rata-rata Siklus I & \multicolumn{2}{|c|}{12.9} \\
\hline & Kategori Aktivitas Peserta Didik & \multicolumn{2}{|c|}{ Sedang } \\
\hline
\end{tabular}

Dari tabel di atas, dapat dilihat rata-rata aktivitas peserta didik pada siklus I adalah 12,9 dengan kategori sedang. Dari pengamatan terhadap peserta didik atau proses pembelajaran berlangsung baik kegiatan individual maupun kelompok diperoleh temuan 1) Keaktifan peserta didik dalam kelas: Peserta didik sudah termotivasi dalam proses pembelajaran. Sebagian besar peserta didik sudah aktif dalam proses pembelajaran. Peserta didik sudah menanggapi saat guru memberi apersepsi. Peserta didik sudah terlibat dalam penggunaan alat peraga, tetapi sebagian peserta didik. Peserta didik dalam kerja kelompok kurang kompak, saat laporan, peserta didik sudah mau menanggapi, tetapi ada sebagian kecil yang belum menanggapi, pemahaman peserta didik terhadap materi pelajaran sudah cukup baik. 2) Keaktifan peserta didik dalam kelompok: Dalam kerja kelompok, masih ada sebagian kecil yang belum tuntas. Dalam mengungkapkan pendapatnya sudah cukup baik, tetapi masih ada peserta didik yang menguasai kelompoknya, sehingga masih ada peserta didik yang kurang menghargai pendapat temannya, dalam diskusi kelompok kurang memanfaatkan tutor sebaya. Dalam menyampaikan laporan, masih ada kelompok lain yang belum memperhatikan pendapat orang lain. 
SHEs: Conference Series 3 (4) (2020) $806-814$

Tabel 2. Hasil Belajar Matematika pada Siklus I

\begin{tabular}{ccc}
\hline Nilai $(\mathrm{m})$ & Jumlah Peserta didik $(\mathrm{f})$ & $\mathrm{m} \times \mathrm{f}$ \\
\hline 30 & 3 & 90 \\
40 & 5 & 200 \\
50 & 3 & 150 \\
60 & 6 & 360 \\
70 & 14 & 980 \\
80 & 6 & 480 \\
90 & 1 & 90 \\
Jumlah & 38 & 2350 \\
Rata-rata & & 61.8 \\
\hline
\end{tabular}

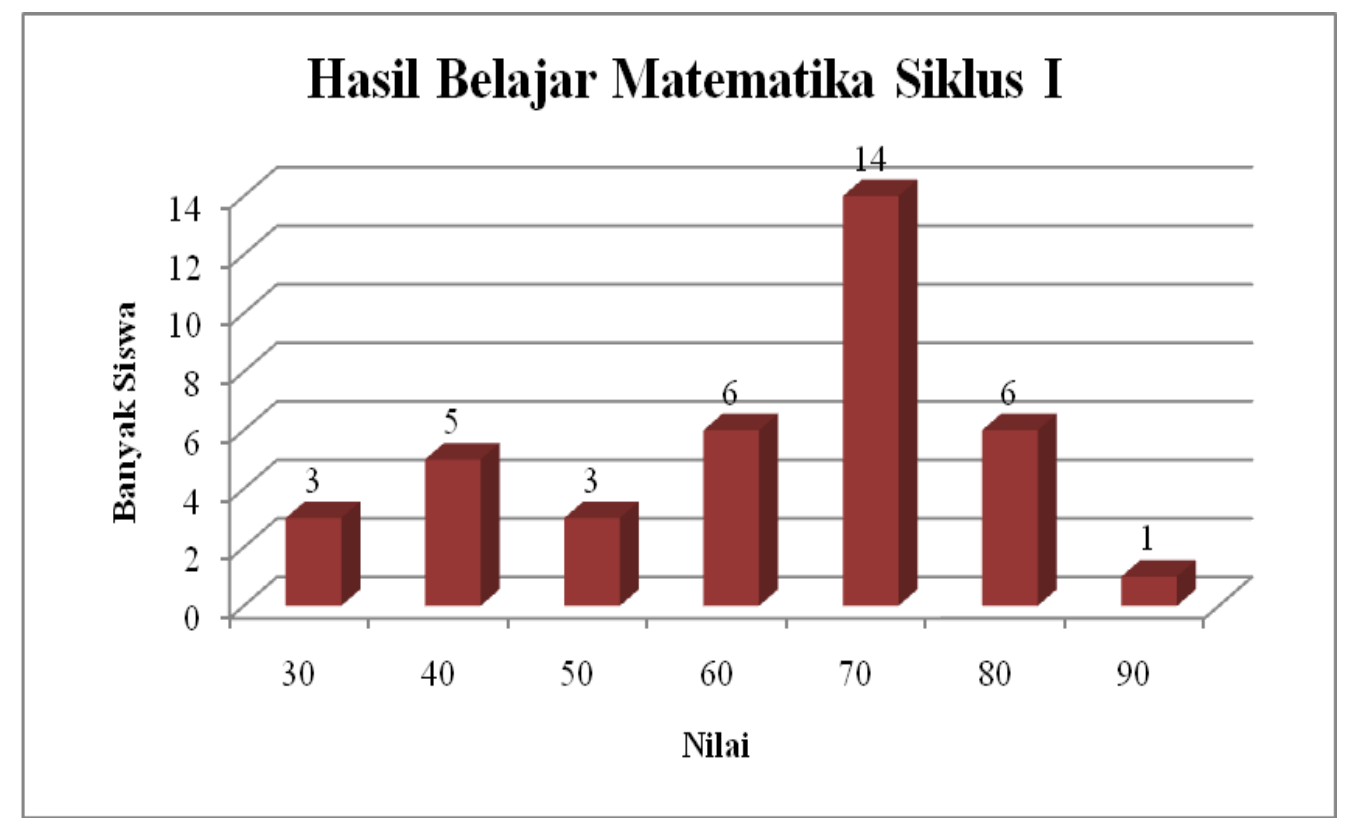

Gambar 2. Diagram balok hasil matematika siklus 1

Berdasarkan tabel di atas maka terjadi peningkatan antara kondisi awal dan siklus 1. Setiap individu peserta didik mengalami peningkatan hasil belajarnya. Peserta didik mengalami peningkatan hasil belajar pada siklus 1. Ketuntasan klasikal juga mengalami peningkatan. Pada hasil belajar matematika siklus 1 diperoleh hasil bahwa 22 peserta didik (57,9\%) sudah tuntas dan 16 peserta didik (42.1\%) belum tuntas dan rata-rata klasikalnya adalah 61,8 .

Berdasarkan refleksi pada siklus 1 maka diputuskan untuk melanjutkan ke siklus II dikarenakan belum mencapai ketuntasan klasikal yang diharapkan dengan melakukan perbaikan pada siklus II. Siklus II membahas materi tentang volume baik dan volume prisma segi tiga.

Berdasarkan pengamatan terhadap proses pembelajaran matematika menggunakan model pembelajaran interaktif pada siswa kelas V SD Negeri Sarireja 01 diperoleh data aktifitas belajar dan hasil belajar pada siklus II sebagai berikut 
SHEs: Conference Series 3 (4) (2020) $806-814$

Tabel 3. Hasil Pengamatan Aktivitas Peserta Didik pada siklus II

\begin{tabular}{|c|c|c|c|}
\hline No & Aktivitas yang diamati & Jumlah & $\begin{array}{l}\text { Rata- } \\
\text { rata }\end{array}$ \\
\hline 1 & Memperhatikan penjelasan guru & 137 & 3.6 \\
\hline 2 & Ikut aktif dalam berdiskusi kelompok & 123 & 3.2 \\
\hline 3 & Menanyakan yang kurang dimengerti & 108 & 2.8 \\
\hline 4 & Merespon pertanyaan & 90 & 2.4 \\
\hline 5 & $\begin{array}{l}\text { Mengkomunikasikan gagasan dalam } \\
\text { kelompoknya }\end{array}$ & 82 & 2.2 \\
\hline 6 & $\begin{array}{l}\text { Perilaku yang menyimpang dalam KBM } \\
\text { (tidur, makan, bermain, berbicara yang } \\
\text { bukan pelajaran, dan sebagainya }\end{array}$ & 119 & 3.1 \\
\hline & Jumlah & 659 & 17.3 \\
\hline & Rata-rata Siklus II & \multicolumn{2}{|c|}{17.3} \\
\hline & Kategori Aktivitas Peserta Didik & \multicolumn{2}{|c|}{ Tinggi } \\
\hline
\end{tabular}

Dari tabel di atas, dapat dilihat rata-rata aktivitas peserta didik pada siklus II adalah 17,3 dengan kategori tinggi. Dari pengamatan terhadap peserta didik atau proses pembelajaran berlangsung baik kegiatan individual maupun kelompok diperoleh temuan sebagai berikut : 1) Keaktifan peserta didik dalam kelas. Peserta didik sudah termotivasi saat pembelajaran. Peserta didik sudah aktif bertanya tentang materi yang belum diketahui. Peserta didik sudah terpusat dalam pembelajaran. Penggunaan alat peraga sudah banyak dilibatkan pada peserta didik. Peserta didik sudah sanggup dalam proses pembelajaran. Peserta didik sudah berani menanggapi pertanyaan dari guru. Peserta didik yang pandai sudah membantu memecahkan masalah pada diskusi kelompok. Hasil evaluasi meningkat. 2) Keaktifan peserta didik dalam kelompok. Peserta didik sudah aktif dan terpusat pada kerja kelompok. Peserta didik sudah kelihatan aktif dalam menyampaikan pendapat. Peserta didik yang lain sudah dapat menanggapi pendapat temannya. Dalam laporan tiap kelompok, anggota kelompok lain sudah bersedia menanggapi.

Tabel 4. Hasil Belajar Matematika pada Siklus II

\begin{tabular}{ccc}
\hline Nilai $(\mathrm{m})$ & Jumlah Peserta didik $(\mathrm{f})$ & $\mathrm{m} \times \mathrm{f}$ \\
\hline 30 & 1 & 30 \\
40 & 2 & 80 \\
50 & 2 & 100 \\
60 & 3 & 180 \\
70 & 11 & 770 \\
80 & 15 & 1200 \\
90 & 4 & 360 \\
Jumlah & 38 & 2720 \\
Rata-rata & & 71.6 \\
\hline
\end{tabular}


SHEs: Conference Series 3 (4) (2020) $806-814$

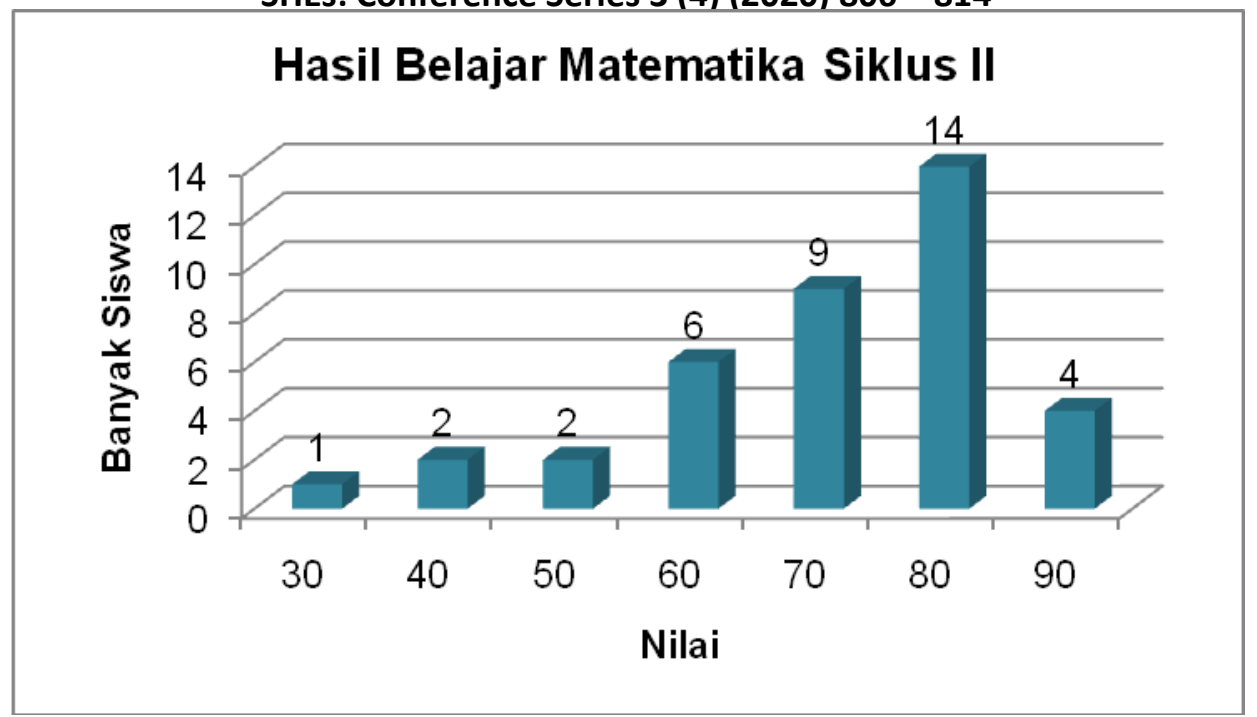

Gambar 3. Diagram balok hasil belajar matematika siklus II

Berdasarkan tabel dan diagram hasil belajar matematika yang diberikan kepada 38 peserta didik diperoleh hasil bahwa 28 peserta didik (73,7\%) telah tuntas, 10 peserta didik (26,3\%) belum tuntas, dan rata-rata klasikalnya adalah 70,5.

Hasil penelitian dari pelaksanaan siklus I sampai siklus II diketahui bahwa akivitas peserta didik mengalami peningkatan. Aktivitas pesra didik pada siklus I ddiperoleh rata-rata skor 12,9 dengan kategori sedang. Sedangkan pada siklus II diperoleh rata-rata skor 17,3 dengan kategori tinggi. Aktivitas peserta didik pada siklus II mengalami peningkatan. Kenaikan aktivitas peserta didik juga terlihat pada pross pembelajaran siklus II peserta didik sudah mulai berani betanya, selalu aktif dalam kegiatan belajar, selalu memperhatikan penjelasan guru, aktif dalam kegiatan kelompok, dan selalu mengerjakan pekerjaaan rumah.

Dari hasil pengolahan data hasil belajar peserta didik kondisi awal pada gambar 1 pembelajaran matematika dengan kompetensi dasar 3.1 mengenalkonsep perpangkatan dan penarikan akar bilangan pangkat dua dan bilangan pangkat tiga sederhana dan 4.7 menggunakan kubus satuan untuk menghitung volume berbagai bangun ruang sederhana, dengan hasil/tes menunjukan bahwa 38 peserta didik kelas V semester II tahun pelajaran 2019/2020 SD Negeri Sarireja 01 mencapai tuntas ratarata nilai 67 keatas ada 18 peserta didik (47,4\%), berarti ada 20 peserta didik (52,6\%) peserta didik yang belum tuntas.

Berdasarkan permasalahan tersebut maka untuk meningkatkan pemahaman peserta didik terhadap materi matematika maka dilakukan perbaikan pembelajaran siklus 1.

Setelah dilakukan perbaikan siklus I dapat dilihat dan dinyatakan ada perubahan peningkatan hasil belajar eserta didik dari 38 peserta didik kelas $\mathrm{V}$ semester II tahun pelajaran 2019/2020 di SD Negeri Sarireja 01 yang mendapat niali 67 keatas yang semula hanya 18 peserta didik $(47,4 \%)$ meningkat menjadi 22 peserta didik $(57,9 \%)$.

Dengan meningkatnya hasil belajar peserta didik tersebut karena peneliti dalam dalam melaksanakan kegiatan perbaikan menggunakan model pembelajaran interaktif, metode ceramah, tanya jawab, dan diskusi serta pemberian tugas dan alat bantu yang menarik.

Berdasarkan pengolahan data dan diskusi dengan supervisor dn teman sejawat maka untuk menuntaskan hasil belajar peserta didik peneliti mengadakan perbaikan pada siklus II yang hasilnya menunjukan peningkatan lebih baik lagi. Pada siklius I yang mendapat nilai 67 keatas 22 peserta didik $(57,9 \%)$ menjadi 28 peserta didik $(73,7 \%)$. 
Peningkatan hasil belajar pserta didik yang lebih baik ada siklus II ini penelitidalam kegiatan proses perbaikan pembelajaran selain menggunakan model pebelajaran interaktif dan metode demontrasi serta memanfaatkan tutor sebaya.

Pada data awal peserta didik yang telah tuntas belajar ada $47,4 \%$ sedangkan yang belum tuntas ada $52,6 \%$. Pada siklus I peserta didik yang telah tuntas balajar ada $57,9 \%$ sedangan peserta didik yang belum tuntas $42,1 \%$. Sebagian besr peserta didik memperoleh nilai dibawah 80 . Berbeda dengan presentase ketuntasan pada siklus II peserta didik yang teah tuntas belajar ada $73,7 \%$ sedangkan pesrta didik yang belum tuntas ada $26,3 \%$. Lebih dari $73 \%$ peserta didik memperoleh nilai diatas 70 . Presentase ketuntasan belaajar pada siklus II telah memenuhi indikator kinerja yaitu telah mencapai 68.

Melalui pemanfaatan model pembelajaran interaktif dapat meningkatkan kualitas proses embelajaran matematika materi menghitung volume balok dan prisma segitiga pada peserta didik kelas V SDN Sarireja 01 tahun pelajaran 2019/2020.

Melalui pembelajaran interaktif dapat meningkatkan aktivitas peserta didik pada mater menghitung volume balok dan prisma segitiga pada peserta didik kelas V SDN Sarireja 01 taahunpelajaran 2019/2020dari kondisi awal aktivitas peserta didik pada kategori rendah ke kondisi akhir pada kategori tinggi. Aktivitas peserta didik mengalami peningkatan sebagian besar peserta didik mempunyai aktivitas pada kategori tinggi. Kenaikan aktivitas peserta didik terlihat juga pada proses pembelajaran pada siklus II.

Melalui model pembelajaran interaktif dapat meningkatkan hasil belajar matematika materi menghitung volume balok dan prisma segitiga peserta didik kelas $\mathrm{V}$ SDN Sarireja 01 Tahun Pelajaran 2019/2020 dari kondisi awal hasil belajar matematika rata-rata 59,7 ke kondisi akhir hasil belajar matematika rata-rata 70,5. Rata-rata hasil belajar pada siklus II telah memenuhi indikator kinerja yaitu telah mencapai 68 .

\section{SIMPULAN}

Berdasarkan seluruh kegiatan penelitian tindakan kelas yang dilakukan dapat disimpulkan bahwa melalui model pembelajaran interaktif pada peserta didik kelas $\mathrm{V}$ SDN Sarireja 01 SDN Sarireja 01 Tahun Pelajaran 2019/2020 dapat meningkatkan: 1) Kualitas proses pembelajaran matematika materi menghitung volume balok dan prisma segitiga pada peserta didik kelas V SDN Sarireja 01 Tahun Pelajaran 2019/2020. 2) Aktivitas peserta didik pada materi menghitung volume balok dan prisma segitiga pada peserta didik kelas V SDN Sarireja 01 Tahun Pelajaran 2019/2020 dari kondisi awal aktivitas peserta didik pada kategori rendah ke kondisi akhir pada kategori tinggi. 3) Hasil belajar peserta didik terlihat dari rata-rata nilai tes formatif yang peneliti berikan pada akhir setiap siklus dan presentase ketuntasan belajarnya. Pada siklus I nilai ratarata yang diperoleh adalah 61,8 dan presentase peserta didik yang tuntas belajar $57,9 \%$ dan peserta didik belum tuntas $42,1 \%$. Pada siklus II nilai rata-rata yang diperoleh adalah 70,5 dan presentase peserta didik yang tuntas $73,7 \%$ dan peserta didik belum tuntas $26,3 \%$.

\section{DAFTAR PUSTAKA}

Arindiono, R.Y., Ramadhani, N. (2013). Perancangan Media Pembeajaran Interaktif Matematika untuk Siswa Kelas 5 SD. Jurnal Sains dan Seni Pomits, 2(1), 28-32

Maryani, D. (2014). Pembuatan Media Pembelajaran Interaktif Bangun Ruang Matematika. Jurnal Speed-Sentra Penelitian Engineering dan Edukasi, 6(2) 1824

Widiyanto, N., Harjono, N. (2017). Penerapan Model Pembelajaran Interaktif dan Hasil Belajar Siswa Kelas 5 SD. Scholaria: Jurnal Pendidikan dan Kebudayaan. 199213 
Depdikbud (1993). Landasan program dan pengembangan kurikulum Pendidikan Dasar 9 Tahun, Garis-garis Besar Program Pengajaran (GBPP) Sekolah Menengah Lanjutan Pertama (SLTP). Jakarta: Yayasan Taruna Nusantara Hamalik, O. (2005). Proses Belajar Mengajar. Jakarta: Bina Aksara Pasaribu dan Simanjuntak. (1982). Proses Belajar Mengajar. Jakarta: Rasito Rusman. (2010). Model-Model Pembelajaran. Jakarta: Rajawali Pers

Sudjana. (2010). Penilaian Hasil Proses Belajar Mengajar. Bandung: Rasdakarya The Liang Gie. (1981). Filsafat Matematika. Yogyakarta: Super Sukses 